\title{
2 枚落し戸の実験からみたロックボルトの挙動
}

\section{BEHAVIOR OF ROCKBOLTS FOUND IN THE EXPERIMENTS OF TWO LOWERING PANELS}

\author{
山本 稔* ·大野一昭** \\ By Minoru YAMAMOTO and Kazuaki OHNO
}

\begin{abstract}
Although the rockbolts are used very often as a main member of supports in NATM, the fact is that there are various understanding of the effects of rockbolts and that there has been no specified way of design. It is because the effects of rockbolts have been recognized mainly through experiences and also because there is no good way of investigation of them.

This study of rockbolts by two lowering panels is a method of examining more positively the mechanical properties of rockbolts presented by our authors, following the previous study by one lowering panel. This series of the experiments by two lowering panels were made to examine the mechanical properties of a group of rockbolts while the experiments by one lowering panel were made to examine the effects of a rockbolt.

This report describes the behavior of rockbolts found through the experiments of two lowering panels including theoretical consideration. And it also describes our view of design of rockbolts.
\end{abstract}

\section{1. はじめに}

トンネルの支保構造として利用されるロックボルトの

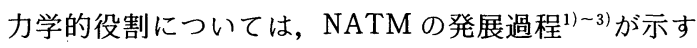
ように, ロックボルトの経験的使用が理論的研究に先行 した関係からいろいろな見解 ${ }^{4)}$ があり，その力学的性質 に対する理解が地山によってまちまちであるのが実状で ある.これはロックボルトが地山と相関して複雑な挙動 を呈するために統一的見解を示しにくいことにもよる が, またロックボルトの本質に関する実証的研究が難し く，的確な検証手法が欠如していることにも原因がある と思われる.

1 枚の落し戸に 1 列のボルトを取り付けて行った実証 的研究5) が塑性地山に対するロックボルトの力学的性質 を究明する有力な手段として利用できることは，すでに 指摘したとおりである.この研究を通じてロックボルト の作用効果は, 自己つり合い作用に基づく地山の一体化 効果として説明することができた。この作用効果によれ ば，ロックボルトはトンネル周辺の地山を一体的に保ち

* 正会員 工博 東京都立大学教授 工学部土木工学科 ( 个158 世田谷区深沢 2-1-1)

** 正会員 佐藤工業(株)中央技術研究所土木研究部 ( ( 243-02 厚木市三田 47-3)
ながら地山とともに変位し, 地山の応力再配分と地山が 本来有する支持力とによってトンネルを自動的に安定化 の方向に導くこと, また, 内的につり合いながら地山を 支持できるために変形能の大きい支保工を形成できるな よ゙, トンネルにおけるロックボルトの基本的挙動を容易 に説明することができる.しかし，この研究ではロック ボルト群によるトンネルの支保機構の解釈が抽象的にと どまるため, そこにおいてロックボルトが受け持つ力学 的役割を具体的に把握しようとすれば，改めて実証的研 究が必要である.

トンネルの支保工をロックボルトによって形成するに

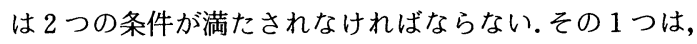
トンネルの掘削面に打設した個々のロックボルトがそれ ぞれ独立に地山を一体化する条件であり，他の 1 つは, ロックボルトを打設した地山が全体として安定する条件 である. 1 枚の落し戸による既報の研究 ${ }^{5)}$ は第 1 の条件 を究明する手段として有効であったが，第 2 の条件の検 討にはロックボルトが群としてトンネルの周辺地山を安 定化するメカニズムの究明が必要である. 6 枚の落し戸 板を用いたアーチ型トンネルの模型実験 ${ }^{6), 7)}$ はこの立場 から実施したものであり, 砂のような塑性地山に掘削す る土被りの浅いトンネルを対象に考究している. しかし ながら，このような実トンネルをじかに模した模型実験 
では現象が複雑にすぎるきらいがあり，ロックボルト群 が受け持つ役割を本質的に究明するには実験条件を単純 化する方が有利である.

2 枚落し戸の模型実験 ${ }^{21}$ は，それぞれ 1 列のボルトを もつ 2 枚の落し戸板を並列して行う実験で，トンネルの 天盤を横断面 2 本のロックボルトで支保する場合に対応 する. 2 本は群の最小単位である. したがって，2枚落 し戸の実験は群として挙動するロックボルトの力学的性 質を調査する最も単純なモデルである。これが研究対象 としてこの実験を取り上げた理由である．次に実験と結 果概要について述べるが，モデルの性質上ここには研究 の主眼をロックボルト群による支保機構の探究に置くこ とにする. また，この研究成果を普遍する試みとしてさ らに実トンネルにおけるロックボルトの挙動についても 推論し，参考に供することにする.

\section{2. 実験装置および実験計画}

\section{（1）装置と基本概念}

実験槽は内のり寸法 $140 \times 110 \times 60 \mathrm{~cm}$ の鋼製砂箱で, その床底面には奥行全長にわたって $32 \times 60 \mathrm{~cm}$ の矩形 の穴があいている．この穴には等大 2 枚の落し戸板が自 由に降下できるように挿入される，砂箱の床底面には厚 めの合板を張り，落し戸の降下変位に伴ってすき間から 砂が漏れるのを防ぎやすくし，また正面には一部に厚板 ガラスをはめ込み，砂と落し戸の移動が観察できるよう にしてある。

落し戸板は厚さ約 $10 \mathrm{~mm}$ のアクリル樹脂板製で，そ の長手方向の中心線上には 6 本のボルトがピッチ $10 \mathrm{~cm}$ で取り付けられている．実験にあたって 2 枚落し戸のス
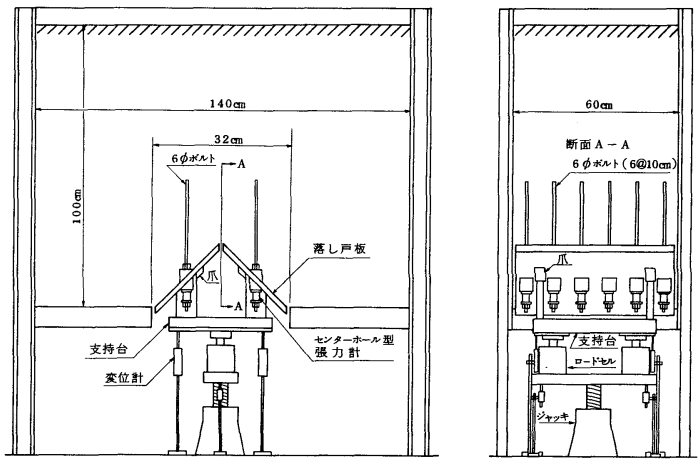

図-1 実験装置

注 1）下記に一部報告されている.

山本 稔・大野一昭・山田 稔：ロックボルトの基礎実験 -2 枚落し戸の実験, 土木学会第 35 回年次学術講演会, III- 265 , 昭 和 55 年 9 月.

山本 稔・大野一昭 - 山田 稔：2 枚落し戸によるロックボ ルトの実験, 土木学会第 36 回年次学術講演会, III -226 , 昭和 56 年 10 月.
パンは砂箱の穴幅に合わせて一定としたから，落し戸板 は傾角によって幅が異なったものになっている.

ボルトは全面接着式ロックボルトに似せるために全長

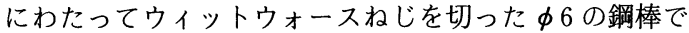
ある.ボルトは図ー1 のように特製のセンターホール型 張力計と半球面ワッシャを介し，ナットで両側からゆる く締めて落し戸板に取り付ける．ボルトと落し戸板の間 には遊びがあり，ボルトは落し戸板に対してヒンジ結合 に近い之考えられる。

地山材料は乾燥した水道用沪過砂で, 砂の粒径は 1 $\mathrm{mm}$ ，均等係数は 1.47 である. また，実験過程で数度 のサンプリングを行い, 砂の単位容積質量と内部摩擦角 を測ったが，その結果はそれぞれ $\gamma_{d}=1.6 \sim 1.8 \mathrm{~g} / \mathrm{cm}^{3}$, $\phi=40 \sim 45^{\circ}$ である. なお, 内部摩擦角は一面せん断試 験による值である.

落し戸板は支持台に載せて砂箱に据え付ける. 支持台 の鉛直反力は 2 台のロードセルによって, 落し戸の降下 変位は支持台に取り付けた変位計によって図一1のよう に計測する．なお，落し戸板には爪が付けてあり，落し 戸板の位置を規制するのに利用する．

上述のように実験装置を構成すれば，落し戸板はそれ 自体で地山を支持できず，ボルトと協力して初めて地山 の支保機構が形成されることになる．2 枚落し戸の実験 は，このような見地からボルト群による地山の支保機構 を追求する実証的手段として計画したものであるが，こ の種の実験に関する報告はいまだ見当たらない。これは

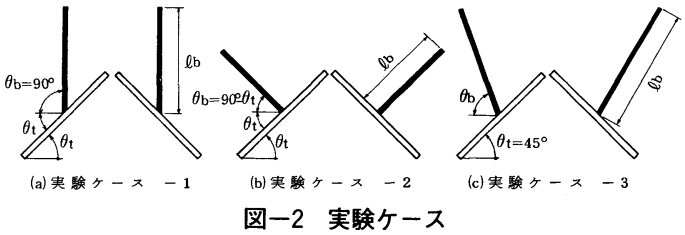

\section{表-1 実験条件}

(a) 実験 タース -

\begin{tabular}{|c|c|c|c|c|c|c|c|c|c|}
\hline$\theta_{\mathrm{t}}^{\mathrm{lb}} \mathrm{b}$ & 0 & 16 & 20 & 24 & 28 & 32 & 36 & 40 & 46 \\
\hline 0 & $2 \mathrm{C}$ & $2 \mathrm{C}$ & $2 \mathrm{C}$ & $2 \mathrm{C}$ & $2 \mathrm{C}$ & $2 \mathrm{C}$ & $2 \mathrm{C}$ & $2 \mathrm{Sc}$ & $2 \mathrm{Sc}$ \\
\hline 15 & $2 \mathrm{C}$ & $2 \mathrm{C}$ & $2 \mathrm{C}$ & $2 \mathrm{C}$ & $2 \mathrm{C}$ & $2 \mathrm{C}$ & $2 \mathrm{Sc}$ & $2 \mathrm{Sc}$ & \\
\hline 30 & $2 \mathrm{C}$ & $2 \mathrm{C}$ & $2 \mathrm{C}$ & $2 \mathrm{C}$ & $2 \mathrm{Sc}$ & $2 \mathrm{Sc}$ & $2 \mathrm{Sc}$ & & \\
\hline 45 & $2 \mathrm{C}$ & $2 \mathrm{C}$ & $2 \mathrm{C}$ & $2 \mathrm{Sc}$ & $2 \mathrm{Sc}$ & $2 \mathrm{Sc}$ & & & \\
\hline 60 & $2 \mathrm{C}$ & $2 \mathrm{C}$ & $2 \mathrm{C}$ & $2 \mathrm{C}$ & $2 \mathrm{Sc}$ & $2 \mathrm{Sc}$ & $2 \mathrm{Sc}$ & & \\
\hline
\end{tabular}

\begin{tabular}{|c|c|c|c|c|}
\hline$\theta_{\mathrm{b}}^{\mathrm{b}} \mathrm{b}$ & 16 & 24 & 28 & 32 \\
\hline 0 & $1 \mathrm{C}$ & $2 S$ & $2 S$ & $2 \mathrm{~S}$ \\
\hline 15 & $1 \mathrm{C}$ & $2 \mathrm{~S}$ & $2 \mathrm{~S}$ & $2 \mathrm{~S}$ \\
\hline 30 & 1C & $2 S$ & 3S & 2S \\
\hline 45 & - & - & - & - \\
\hline 60 & $1 \mathrm{C}$ & $2 \mathrm{~S}$ & 3S & $2 \mathrm{~S}$ \\
\hline 75 & $1 \mathrm{C}$ & $2 \mathrm{~S}$ & $2 \mathrm{~S}$ & $2 S$ \\
\hline 90 & - & - & - & - \\
\hline
\end{tabular}

(b) 実験 クース -

\begin{tabular}{|c|c|c|c|c|c|c|c|c|c|}
\hline $\begin{array}{c}\mathrm{lb} \mathrm{b} \\
\theta_{\mathrm{t}}^{\mathrm{cm}}\end{array}$ & 0 & 16 & 20 & 24 & 28 & 32 & 36 & 40 & 46 \\
\hline 0 & - & - & - & - & - & - & - & - & - \\
\hline 15 & - & $2 \mathrm{C}$ & $2 \mathrm{C}$ & $2 \mathrm{C}$ & $2 \mathrm{C}$ & $2 \mathrm{Sc}$ & $3 \mathrm{Sc}$ & $2 \mathrm{Sc}$ & $2 \mathrm{Sc}$ \\
\hline 30 & - & $2 \mathrm{C}$ & $2 \mathrm{C}$ & $2 \mathrm{C}$ & $2 \mathrm{Sc}$ & $3 \mathrm{Sc}$ & $2 \mathrm{Sc}$ & & \\
\hline 45 & - & $2 \mathrm{C}$ & $2 \mathrm{C}$ & $2 \mathrm{Sc}$ & $3 \mathrm{Sc}$ & $2 \mathrm{Sc}$ & & & \\
\hline
\end{tabular}

注: 表中において

数字; 同じ実験の実施回数 $\mathrm{C} ;$ 落し戸が崩落した実験 $\mathrm{S}$; 落し戸が自立した実験 $\mathrm{S}_{\mathrm{c}}$; 落し戸の自立が綝り返 された実験 
既報 ${ }^{5)}$ 同様に研究の目的が明確でない限り模型実験に 意義が認められないことによると思われる.

\section{（2）実験条件}

実験は落し戸板の傾向 $\theta_{t}$, ボルトの長さ $l_{b}$ およびボ ルトの設置方向角 $\theta_{b}$ をパラメーターとし, 図一2に示 す 3 種の実験ケースと $l_{b}$ とを組み合わせた表一1の実 験条件について実施する. 表中の数字は同一実験の繰返 し回数である.

実験条件はすべて落し戸の支間中央に対して対称であ るから，力のつり合いは鉛直方向の成分についてだけ考 えればよい．実験ケース-1 はボルトを鉛直方向に設置 する場合であり，ボルトの軸力が力のつり合いに占める 役割を考察するのに有利である. 実験にあたってはこの 点に着目し，ケース-1を主体として行う. 実験ケース -2 はボルトを落し戸板に直交して設置する場合であり, 通常使用するロックボルトの打設方向に合わせたもので あるが，ケース-1 と対比して $\theta_{b}$ の影響を調べるのに用 いる. 実験ケース -3 は $\theta_{t}=45^{\circ}$ に固定した場合で, ケ一 ス-2 を補足して $\theta_{b}$ の影響を詳細に検討するのに用いる が，さらにケース-2とともにその実験結果がケース-1 に対する力学的解釈に従って説明できる可能性を追求す るのに利用する。なお，実験計画にあたってケースー1 に主眼を置くことにしたのは，ボルトのせん断力を直接 計測する適当な手段がないし，また土圧を計測して推測 するには精度に問題があるため, ケース -2 と-3 が現象 の基本的調査に適さないと判断したことによっている.

\section{3. 実 験 概 要}

\section{（1）実験手順}

図一1 を参考にし，落し戸板の設置から実験終了まで の手順を説明する.

a）ボルトを取り付けた落し戸板を支持台に載せ，さ らにロードセルを付けたジャッキの上にこれを置く．落 し戸板の位置が砂箱の穴に合うようにし, 落し戸が自由 に上下できることを確かめた後, 落し戸板を仮止めして 動かないようにする.

b) 落し戸板と穴とのすき間から砂が漏れないよう に薄手の軟らかい不織布で目張りする．不織布は落し戸 の降下変位によって引張られないように余裕をとってお く. また落し戸板の突き合せ面については，ヶース-1 の場合すき間は適宜でよいが，ケース-2 と-3の場合に は $1 \mathrm{~mm}$ 以上のすき間を残して互いにせり持たないよう にする.この突き合せ面にはいずれのケースにおいても 砂がかみ込まないようにカバーを掛ける.

c) 砂は $\gamma_{d}=1.7 \mathrm{~g} / \mathrm{cm}^{3}$ を目標に約 $1 \mathrm{~m}$ の落下高さで 少量ずつ自然落下させ, 深さ $1 \mathrm{~m}$ まで層状に詰める.

d) 砂詰めを完了した後, ボルトを止めている落し
戸板下側のナットをゆるめて張力計の応力を解放する. 張力計の 0 点を設定して再びナットをゆるく締めてボル トを固定する.

砂詰めによって支持台はわずかであるが沈下するか ら, その上に載っている落し戸も移動してボルトには張 力が発生する. 上の操作はこの張力を解放するものであ る. 一方，この操作によって支持台の反力はふえるが, この状態の支持台反力が計測の初期值で, このとき落し 戸の降下変位は 0 とする.

落し戸に作用する土圧の合力は鉛直方向の成分をもつ にすぎないから，ボルトに応力が発生しない限り，支持 台反力は合土圧につり合う.ボルトに張力が発生すれば, その合力の鉛直成分を合土圧から差し引いたものが支持 台反力につり合うことになる.なお, 支持台反力の計測 には落し戸板の自重は除去されているが, ボルト張力の 計測值には自動的にその影響が入ることに注意する必要 がある。

e）落し戸の降下変位は支持台の平均変位で測る. 落 し戸板はボルトの配置線のまわりに回転変位を許容しな がら降下すると考えられるから, 計測される変位はボル 卜位置における落し戸の降下変位に相当すると判断され る.なお，ボルトを設置しない場合には落し戸板には回 転変位が生じないが, 計測変位の解釈は同様である.

f) 落し戸の降下変位, 支持台反力およびボルト張力 の計測は，d）で設定した初期值から始め，落し戸の降 下変位約 $0.2 \mathrm{~mm}$ の増加を目安として計测する. そして, 落し戸が自立するかまたは降下変位が $5 \mathrm{~mm}$ 程度になる まで計測を継続する．落し戸の降下速度は $1 \mathrm{~mm} / \mathrm{min}$ を標準とし, 計測にあたっては一時的に降下を停止する.

g）落し戸の自立は支持台反力が 0 になることに よって知ることができる. 落し戸が自立した後, 逆に ジャッキをせり上げて落し戸板を再び支持台で支持す る. そして, 所定の計測を行いながらナットをゆるめ, たとえば図ー5のように大部分のボルト張力を解放す る. 以後の実験操作は, f) と同様である，再び落し戸が 自立すれば, 続いて同じ操作を繰り返す。このような操 作は, 自立機構の究明をはじめ実験の信頼性を検証する のに役立つ.ただし，ケース-3については繰り返しの 操作は行わない.

\section{（2）実験 経 過}

実験は上述の手順に従って実施した. 実験にあたって は現象の再現性を調べる意から同一実験を少なくとも2 回行った. そして, 計测した支持台反力またはボルト張 力の極值について相対誤差を調へ，その差異が $15 \%$ を 超える場合にはさらに同じ実験をもう 1 回追加した. 実 験にあたって設けたこの管理規準は, ボルトに付けた張 力計の計測誤差を考慮して仮に定めたものである. 張力 
計の計測誤差にはボルト軸力の偏心による影響が大きい と思われる. 表一1において実験回数を示す数字に続く 記号のうちC は落し戸が崩落, S は落し戸が自立した ことを表わしている．また記号 Sにはさらにサフィッ クスCを付けたものがあるが，これは先の実験手順 $\mathrm{g}$ ) による繰り返し操作を意味している.

既述したボルトの張力は端部を除いた 8 本について計 測するのを標準としたが，これは単に計測機器の都合に よる処置にすぎない，このため，ボルトの全張力は 8 本 の計測値の合計を 1.5 倍して求めた。これに対して一部 の実験では検証のために 12 本の全ボルトについて張力 を計測し，両者を比較したが，その差異は数パーセント に収まっていた．壁面効果の影響は，落し戸幅 $32 \mathrm{~cm}$ に対して奥行を $60 \mathrm{~cm}$ にすることにより相対的に軽減 できたと思われる。

ガラス悹からの観察によれば，落し戸周辺の砂の移動 は全実験で同様であり，鉛直方向に近い。ケース-1の 実験についてはボルトの方向が鉛直のため, 落し戸の鉛 直方向に対する力のつり合いに問題がなく，特に説明す ることはない.ケース -2 と-3 の実験においてボルトが 鈆直方向から傾く場合には，砂はボルトに斜交して移動 することになるから，ボルトには曲げが発生すると思わ れる.この結果，落し戸の鉛直方向の力のつり合いに水 平土圧とボルトのせん断力が影響することになる．先に ケース-1の実験に主体を置くことにしたのはこのため である．なお，ここに落し戸の力のつり合いにボルトの せん断力が顕著に影響する例としてケースー3における $\theta_{b}=0$ の実験を挙げることができる.この場合 $l_{b} \geq 24$ $\mathrm{cm}$ において落し戸は表一1 のように自立する. しかし， 同じ実験条件でボルトの代わりにアンカーヘッド付きの 針金を用いた別の補足実験では，落し戸は自立していな い.これは明らかにボルトのせん断抵抗が落し戸の自立 に関与することを示している。

\section{4. 実験 結果}

図ー3〜9は実験結果の例である. 他の実験について も結果はこれらと同様な傾向である，既述のように，支 持台反力には計測開始にあたって多少不明確なところが 残っている. 図において支持台反力を降下変位初期にお いて省略してあるのは，この点を考慮したものである. ボルトの有無にかかわらず, 2 枚落し戸の反力は, 落し 戸板に作用する合土圧に落し戸板の自重を加えたもので 与えられるとする.ボルトがない 2 枚落し戸の実験では 支持台反力が合土圧に相当し，初期地山応力として全土 被りの土圧からゆるみ土圧に至る応力再配分過程の合土 圧が，これによって表示される．いま，2枚落し戸の実 験においてこの合土圧がボルトの存在に影響を受けない
とすれば，ボルトがない 2 枚落し戸の実験における落し 戸の反力は,ボルトによって支持されなければならない. 図一3 はこの意図に基づいて示したものであり，図一4 ９に併記して後の理論的考察に利用する.

図一 3 で特に $\theta_{t}=0$ の場合は既報 ${ }^{8,9)}$ 之研究対象が同じ である. いま村山教授の研究を用いて落し戸の合土圧を 求めれば, $\gamma_{d}=1.6 \mathrm{~g} / \mathrm{cm}^{3}, \phi=44^{\circ}$ に対して $36.8 \mathrm{~kg}$ で ある. 実験結果は降下変位が $1 \mathrm{~mm}$ の位置で $30.2 \mathrm{~kg}$ で あり, 理論值に比してやや小さい. しかし，土圧の発生 機構は本質的に同じであるから，比較は実験結果の信頼 性に対する判断資料として役立つと思われる.

次には 2 枚落し戸にボルトを付けた場合について実験 結果から直接考察できる挙動について説明する.

\section{（1）実験結果全般について}

表一1 から明らかなように, どの実験ケースにおいて もボルトが長くなると落し戸は自立できるようになる. 図一4，6，8 は崩落した場合, 図一5，7，9 は自立した 場合の例であるが，両者の違いは支持台反力によって明 白である. 自立する場合に行った繰り返し操作において は一度自立すると何回も自立できること，また，自立時 のボルト張力はほぼ同じ大きさになっていることがわか る、これは落し戸の自立条件が降下変位の大きさによっ て極端に変わらないことを示すとともに実験の信頼性を 裏付けるものである.

後で詳細に論ずるが，図一 4 と 5 の場合には支持台反 カとボルトの張力の和が落し戸の反力につり合うこと は, 落し戸板とボルトの配置から明らかである.ここに 落し戸の反力は落し戸板に作用する合土圧に落し戸板の 自重を加えたものである. いま落し戸の反力がボルトの 有無にかかわらず図一3で与えられるとすれば，これか ら逆に支持台反力を差し引いてボルトの張力を推定する

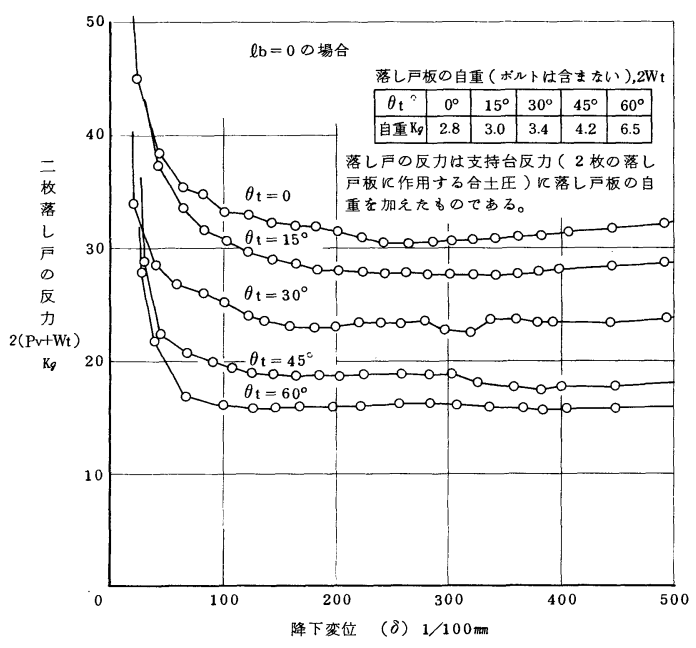

図一3 ボルトのない2 枚落し戸の反カと降下変位 
ことができる. 図中の黒丸はこのようにして求めたボル トの張力である.ただし，図一5では簡単のために落し 戸の自立時 $\left(T_{1}, T_{2}, \cdots\right)$ と繰り返し操作の始点 $\left(T_{1}^{\prime}\right.$, $\left.T_{2}^{\prime}, \cdots\right)$ に対応するボルトの張力 $\left(S_{1}, S_{2}, \cdots ; S_{1}^{\prime}, S_{2}^{\prime}\right.$, …）についてだけ黒丸を示すにとどめている. 図はこの 処理が妥当なことを示しており，結果として次のように 考えられる.

a）落し戸板に作用する土圧は，ボルトの存在に影響 を受けないか, また受けるにしても事実上無視してよい.

b) ボルトには使用条件に応じて相応な張力が発生 する．ボルトが短く落し戸が自立できない場合, ボルト にはその引抜き抵抗力这2)に相当する応力が発生する.

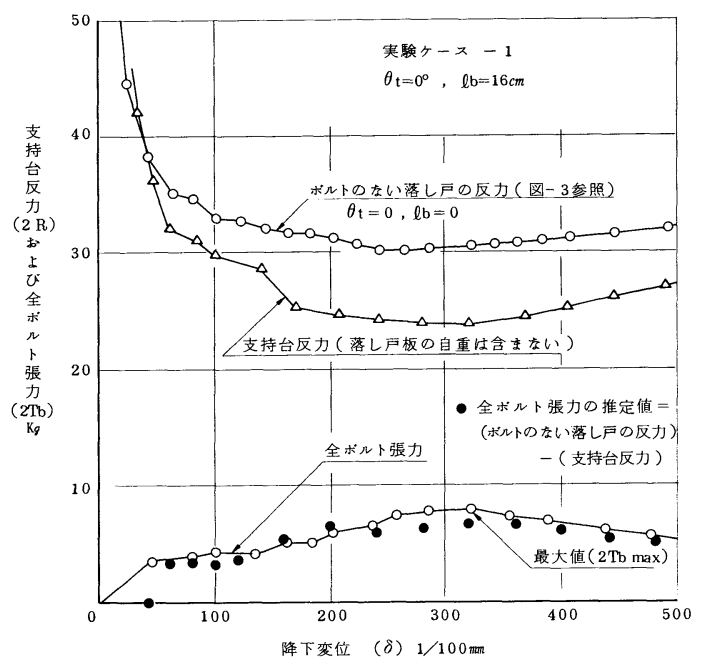

図-4 実験ケース-1 の計測結果例，その 1

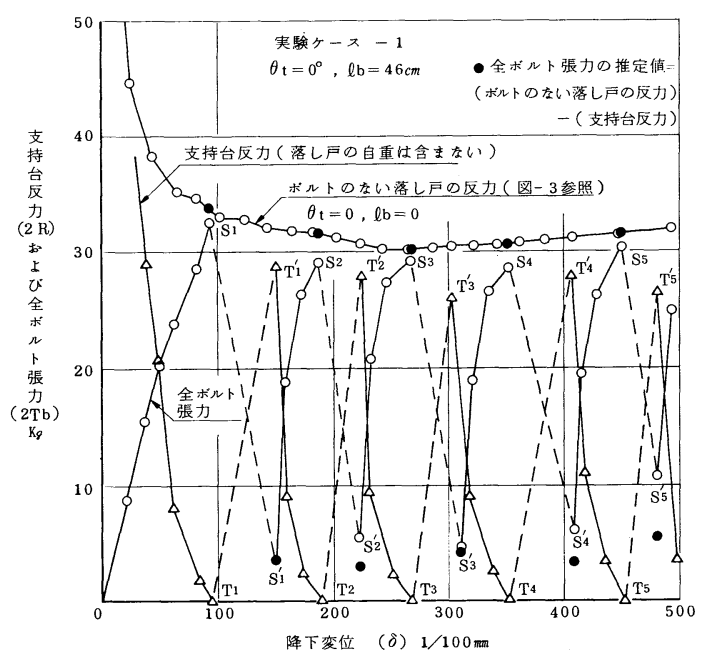

図一5 実験ヶース-1の計測結果例，その 2

注 2）落し戸とともに用体的に動く地山部分には，引抜き抵 抗力が発生しないことに注意する必要がある.
ボルトが長くなって落し戸が自立する場合，ボルトには 落し戸板に作用する土圧につり合う応力が発生する。こ のとき, 落し戸の降下変位は地山とボルトの条件に支配 される.

この考え方は 5. 理論的考察において論理を展開する 根拠になっている. 図一6〜9の黒丸は，この普遍した 論理によるボルト張力の推定值である。ここでも考え方 の妥当性は明らかである。なおここに例示した以外の 実験においても結果は同様である.

上の a）とb) の記述は，ボルトの自己のつり合い作 用による地山の一体化効果として 1 枚落し戸の実験 ${ }^{5}$ か らすでに説明したものであり，落し戸板が 2 枚またはそ れ以上になってボルトが群として挙動する場合にも同じ 作用効果の枠内にあることを示している．この事実は，

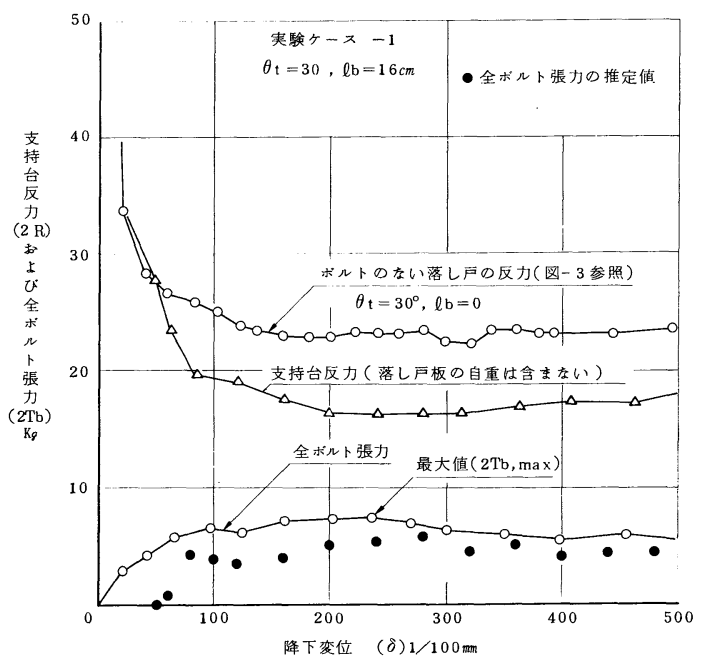

図一6 実験ヶース-1 の計測結果例，その3

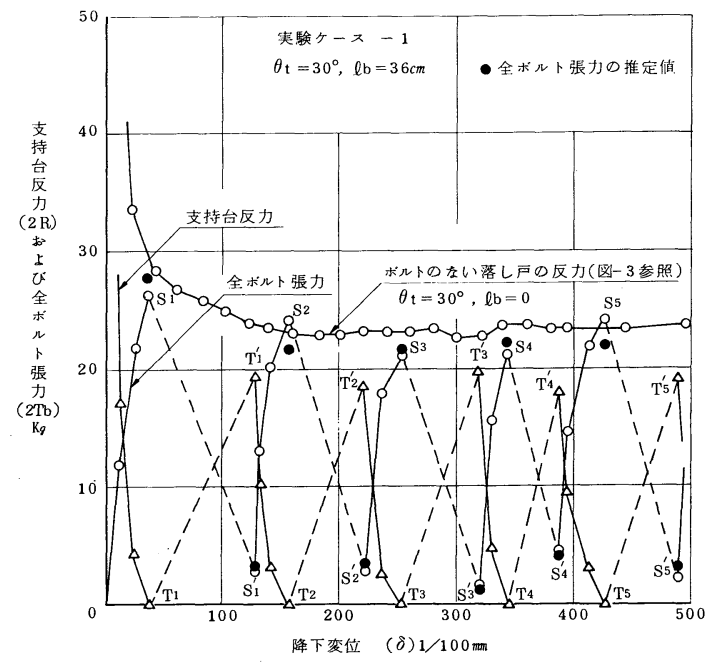

図-7 実倹ケース-1 の計測結果例，その4 
ロックボルトの作用効果の本質を追求するにあたって重 要であると考えられる。

\section{（2）ボルトの張力について}

2 枚落し戸の降下変位に応じて落し戸上方の砂にゆる みが発達するが，このとき移動する砂の主方向は，実験 条件にかかわらず鉛直方向に近い.したがって, 実験ケ一 ス-1におけるボルトの張力発生機構は, 落し戸ととも に剛体的に変位する地山部分の形状が落し戸板の斜角 $\theta_{t}$ に関係なく同じようになっている地山に対するボルトの 引抜き抵抗力として,張力が発現するものと考えられる. 図一10は，この観点から落し戸が崩落する実験につい てまとめた全ボルト張力の最大值とボルト長さの関係で ある．実験結果が図示のように 1 つの曲線に回帰できる ことは，上述の推測が妥当であることを裏付けている.

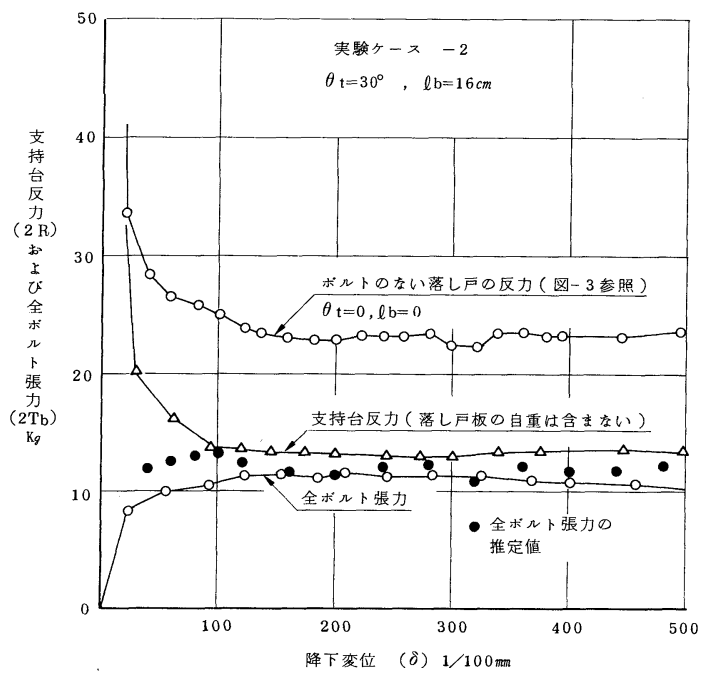

図ー8＼cjkstart実験ケース-2の計測結果例，その1

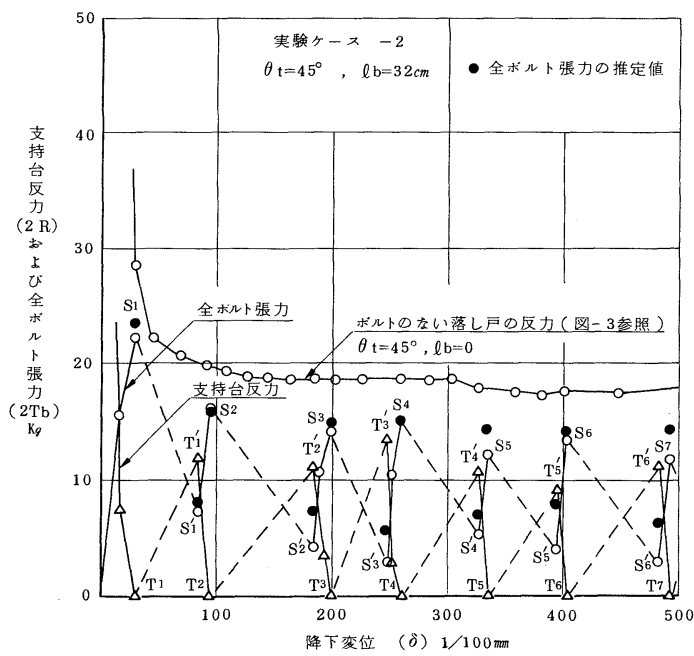

図-9＼cjkstart実験ケース-2の計測結果例，その 2
これはまた実験ケース-1に対するボルトの引抜き抵抗 力が図ー10から推定できることを意味する. 先に（1）, b) の前半で述べた推論に上の結果が考慮されているこ とはいうまでもない.

実験ケース-2におけるボルト張力は，たとえば図一6 と8からわかるように，ボルト長さが同じであっても実 験ケース-1に比して大きくなっている，そして，この 傾向は $\theta_{t}$ が大きくなるほど顕著である．これは，実験 ケース-2の場合には砂の移動方向がボルトと交差する ようになるため， $\theta_{t}$ が大きくなるほどボルトはゆるみの 少ないところに定着される傾向が強まり，引抜き抵抗力 が大きくなった結果であると考えられる，図一10に実 験ケース-2 と-3 の資料を除外したのはこのためである. ただし，落し戸板に作用する土圧が実験ケース-2と-3 においてもボルトの存在に影響されないことは，(1) で述べたとおりであることに注意する必要がある。相違 は，ボルトの地山拘束力の差による降下変位の性状に現 われるにすぎない。

（3）ボルトの設置方向について

既述のように，落し戸板に作用する土圧はボルトの存 在に影響されないから，土圧の大きさと作用方向とは落 し戸によって定まっていると考えることができる．この ような条件のもとでは，ボルトが土圧の作用方向に対し てある角度内に設置されていれば，土圧とのつり合い関

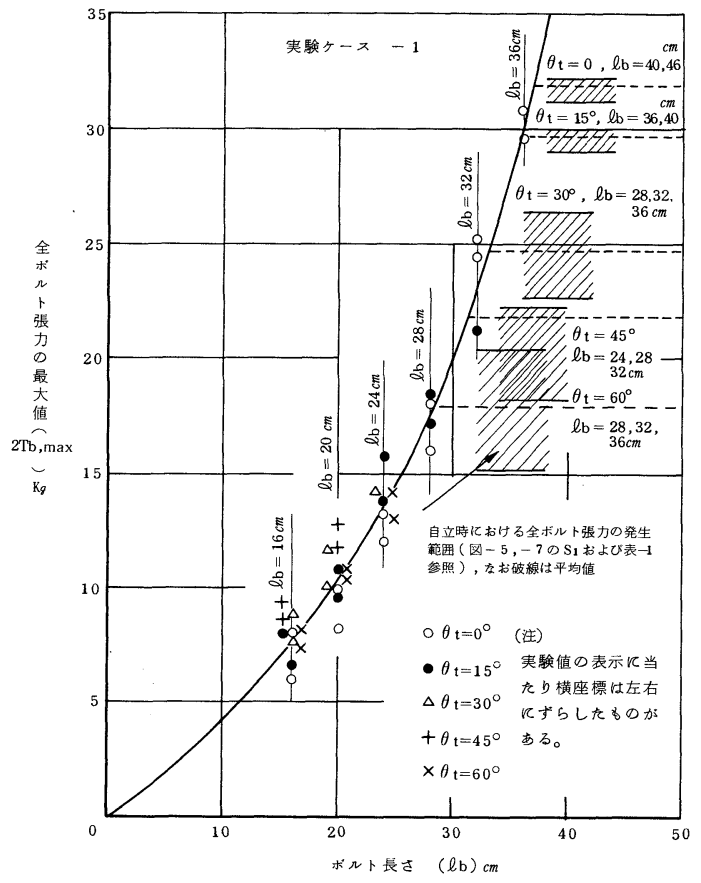

図一10 実験ケース-1 における全ボルト張カの最大值とボルト 長さとの関係 
係から定まるボルト張力には大きな差異がでないことを 予測することができる．この推測の妥当性は，次の 5 . 理論的考察において明確にされるが，このことからボル 卜の有効な設置方向をボルト張力から判断することは難 しいと思われる.

実験ケース-3 はボルトの効果的設置方向についての 調査を意図したものであり，図一11は，実験結果とし て参考までに示した落し戸の降下変位とボルトの設置方 向との関係である. 図によれば $\theta_{b}=45^{\circ}$, すなわち落し 戸板に直交してボルトを設置した場合が変位の拘束性に やや優れている.これに対してボルト張力には，図一13 からわかるように明確な傾向は認められず，上述の推測 を裏付ける結果になっている.このような観点から，ボ ルトの有効な設置方向をボルト張力の実験結果によって 指摘することは難しい. あえて判断すれば, ボルトの設 置方向には許容度が大きいといえる.なお，一般的見解 としてボルトを引張り材として使用する限り，ボルトは 地山のひずみまたは応力の主方向に向けて設置する方 が，ボルトにせん断力成分を排除できる点，またこの方 向でゆるみ域の幅が狭いと考えられる点などから合理的 であると思われる.

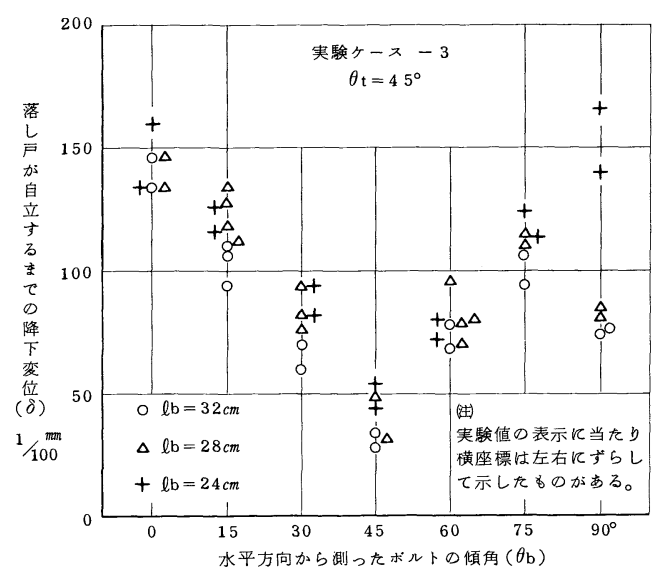

図-11 落し戸が自立するまでの降下変位とボルトの設置方向 との関係

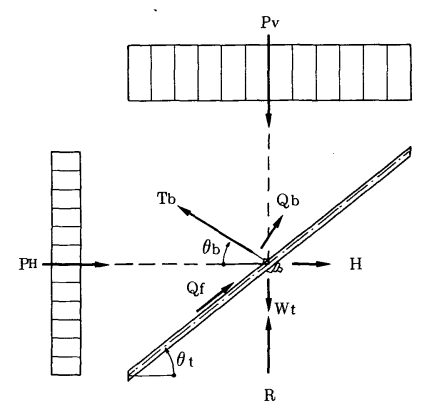

図-12 落し戸板に作用するカのつり合い

\section{5. 理論的考察}

対称性から片側の落し戸板だけを取り上げ，作用する 諸力を示せば図一12のとおりである.この落し戸板に 働く合土压の鉛直成分 $P_{V}$ と水平成分 $P_{H}$, 落し戸板の 自重 $W_{t}$ および落し戸板と地山の間に働く摩擦力 $Q_{s}$ に 対し, 全ボルト張力 $T_{b}$ とせん断力 $Q_{b}$, 支持台の鉛直 反力 $R$ と水平反力 $H$ とがつり合う. ボルトは落し戸板 の中央線上に配置されているし，また落し戸板に対して ヒンジのように結合されているから， $P_{V}$ と $P_{H}$ の作用 線は，土圧の分布形状にかかわらず，落し戸板の中央を 通るし， $R, H, W_{t}$ および $Q_{f}$ も実験装置の構造から落 し戸板の中央を通って作用する．方向力のつり合いを落 し戸板に直交する方向とこれに沿う方向について作れば

$$
\begin{aligned}
& \left(P_{V}+W_{t}\right) \cos \theta_{t}+P_{H} \sin \theta_{t}=T_{b} \sin \left(\theta_{t}+\theta_{b}\right) \\
& \quad+Q_{b} \cos \left(\theta_{t}+\theta_{b}\right)+R \cos \theta_{t}-H \sin \theta_{t} \\
& \left(P_{V}+W_{t}\right) \sin \theta_{t}-P_{H} \cos \theta_{t}=-T_{b} \cos \left(\theta_{t}+\theta_{b}\right) \\
& \quad+Q_{b} \sin \left(\theta_{t}+\theta_{b}\right)+R \sin \theta_{t}+H \cos \theta_{t}+Q_{f} \\
& Q_{f} \text { については } \mu \text { を摩擦係数として } \\
& Q_{f}=\mu\left(P_{V} \cos \theta_{t}+P_{H} \sin \theta_{t}\right)
\end{aligned}
$$

式（1）を $T_{b}, Q_{b}$ について解けば

$$
\begin{aligned}
T_{b}= & \left(P_{V}+W_{t}-R\right) \sin \theta_{b}+\left(P_{H}+H\right) \cos \theta_{b} \\
& +Q_{f} \cos \left(\theta_{t}+\theta_{b}\right) \\
Q_{b}= & \left(P_{V}+W_{t}-R\right) \cos \theta_{b}-\left(P_{H}+H\right) \sin \theta_{b} \\
& -Q_{f} \sin \left(\theta_{t}+\theta_{b}\right)
\end{aligned}
$$

式（2）を図一と 5 の場合に当てはめれば, $\theta_{t}=0^{\circ}$, $\theta_{b}=90^{\circ}$ として次の関係式が得られる.

$$
2 T_{b}=2\left(P_{V}+W_{t}\right)-2 R
$$

図中の黒丸はこの式によって求めたものであるが，そ のとき $2\left(P_{V}+W_{t}\right)$ として実験条件が異なる図ー3の結 果が利用できたことは, ボルトの挙動を究明するにあ たってきわめて重要である.

この実証的結果を拡張解釈し， $\theta_{t}$ 亡 $\theta_{b}$ が任意に与え られる場合にも，ボルトの存在が土圧の発生機構に影響 しないとして式（2）の適用を試みる. 計算にあたって 水平土圧 $P_{H}$ は不明のため, 目安として主働土圧係数 $K_{a}=0.180$ を用いて $P_{H}=0.180 P_{V}$ とする. また摩擦係 数は $\mu=0.15$ である. さらに落し戸が崩落する図一6 8 では簡単のために水平反力 $H=0$, 落し戸が自立する 図ー7と 9 において $\mathrm{S}$ 点では $R=H=0$ は自明である が, $\mathrm{S}^{\prime}$ 点では図一 6 と 8 に準じて $H=0$ とする. 図一6 〜9の黒丸は, このような条件で計算した結果であるが, 図一 4 と 5 の黒丸と同様に全体として実験值をよく説明 することができる.

現象に対する解釈の信頼性をさらに追求するため, 実 験ケース-3において落し戸が自立した実験のボルト張 力を計算值と比較したものが図一13である. 既述のよ 


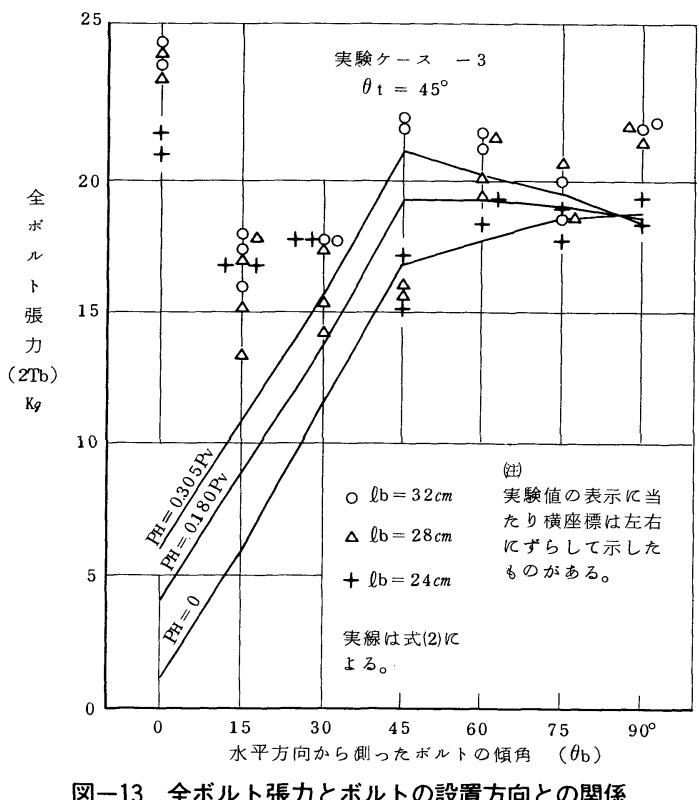

うに，ボルト張力の実験値には設置方向に対して明らか な傾向がなく， $\theta_{b}$ が小さくなるにつれてやや減少する ようにみえるにすぎない．これに対して計算値も同様な 大きさと傾向とを示している．ただし， $\theta_{b}<30^{\circ}$ で計算 值は実験値から急激に遠ざかるが，これはボルトの設置 方向の関係からボルトに発生する張力が $P_{H}$ に影響し, この領域で $P_{H}$ が急増する可能性があるにもかかわら ず，それが計算に反映されていないためであると考えら れる. さらに $\theta_{b}=0$ の場合には, 鉛直方向の力のつり合 いはボルトのせん断力に依存しなければならない。実験 に用いたボルトは合土圧に対してせん断強度が極端に大 きく，そのつり合いの結果として落し戸が自立できたと 思われる，ボルトを引張材として利用する実情からみれ ば， $\theta_{b}$ が小さい場合はむしろ例外として取り扱うべき であろう。なお，ここに計算值を正しく評価するには水 平土圧 $P_{H}$ の実測値が必要である。 しかし， $P_{H}$ の計測は 断念したため, 図には主㗢土圧 $P_{H}=0.180 P_{V}$ のほかに $P_{H}=0$ と $P_{H}=(1-\sin \phi) P_{V}=0.305 P_{V}$ の場合の計算値 も参考として示してある.

\section{6. 実験結果からみた実トンネルにおけるロッ クボルトの挙動について}

模型実験の結果から特に砂のような塑性地山の実トン ネルを対象に若干の考察を試みる. しかし，本質が同じ である限り，他の地山条件に対しても拉張解釈すること は容易であると思う。

（1） ロックボルトが受け持つ支保エとしての役割に ついて
ボルトが支持する荷重は地山から作用するゆるみ土圧 であるという実験結果に着目すれば, 荷重支持という点 からはロックボルトの役割も鋼アーチ支保工と同じであ る.ロックボルトが鋼アーチ支保工と本質的に相違する ところは, 反力を荷重発生源である地山へ直接還元しな がら地山を支持するという反力の伝達機構にある. した がって,ロックボルトには明確な支点が存在しないから， ロックボルトは地山を一体的に挙動させるが, 地山の変 形は拘束できず，地山はそれ自体の力学的性質に従って 挙動することになる．これは, 著者が先に自己つり合い

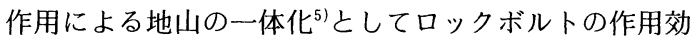
果を説明した挙動の枠内にあり，地山条件に支配されず 常に認められることである.

ロックボルトはその反力を引抜き抵抗力に依存する. したがって, 反力は地山との相対変位によるせん断応力 としてロックボルトまわりに分布し，集中的に作用する ことはない。これはロックボルトがもつ支保工としての 特徵であり, 軟弱な粘性地山を含めた塑性地山の支保工 として有用であることを教えるものである.

弾性的に挙動する地山のトンネルにおいては，たとえ 地山がブロッキーであっても, ロックボルトはトンネル を安定させるうえで基本的には反力を必要としない。こ のような場合のロックボルトは地山内の相対変位を拘束 し,一体的に挙動させる役割を受け持つことになり,ロッ クボルトには局部的に応力が発生する.

（2）ロックボルト工の設計について

実験結果とその考察を踏まえ, ロックボルト工の設計 は次の条件によって行うことができる.

a）ロックボルトはトンネルの安定化に必要な力がト ンネル掘削面を通じて地山に導入できる構造と強度を有 すること．

b) トンネルの安定化に必要な力は断面形状の同じ 素掘りトンネルの安定化に必要な掘削面の力として定め ることができること.

この考え方は塑性地山を対象としたものであるが，既 述のロックボルトの作用効果に対する見解之同様, 地山 条件に支配されるところがないから，一般の地山に対し ても適用することができる，なお，ロックボルトの設計 荷重はb）のように素掘りトンネルの挙動解析によって 定まるから，ロックボルト工の設計は簡明になると思わ れる。

設計手法を具体的に説明する参考として本模型実験に 用いたボルトを設計してみよう. 2 枚落し戸の安定に必 要な反力は図一3によって与えられる。これは素掘り卜 ンネルの安定化に必要な掘削面の力主3)に相当する. ま

注 3)この力を与える図ー3 は概念的に Fenner-Pacher 曲線 と同じである. 
た，図一10 は実験ケース-1におけるボルトの引抜き抵 抗力涪) とボルト長さの関係である. 例として $\theta_{t}=0, \theta_{b}$ $=90^{\circ}$ の場合を取り上げる. 図一 3 から落し戸の安定に 必要な反力を $2\left(P_{v}+W_{t}\right)=35 \mathrm{~kg}$ とすれば, 5 . の式 (3) から $R=0$ として全ボルト張力 $2 T_{b}=35 \mathrm{~kg}$ が求まる.

また, ボルトの所要長さは図一10から $l_{b} \doteqdot 38 \mathrm{~cm}$ と推 定される.このボルト長さによって落し戸が自立できる ことは実験結果から明らかである。一方，ボルトと地山 の間に相対変位がないとすれば，落し戸が自立するまで の降下変位は図一 3 から落し戸の反力 $35 \mathrm{~kg}$ に対応する 変位として $\delta \doteqdot 0.7 \mathrm{~mm}$ である. 図一5において $S_{1}^{\prime} S_{2}$, $S_{2}^{\prime} S_{3}, \cdots$ の変位は主としてボルトと地山の相対変位に よるものと考えられ，約 $0.4 \mathrm{~mm}$ である. 図一5におい ては $l_{b}=46 \mathrm{~cm}$ であるが, $l_{b}=38 \mathrm{~cm}$ ではボルトと地山 の相対変位がこれより大きくなると思われ，地山との相 対変位を無視したボルトの設計では信頼性に問題が残 る. そこで, 自立までの降下変位を $\delta=0.7+0.4=1.1$ $\mathrm{mm}$ と推定し直せば, 図一 3 から $2\left(P_{v}+W_{t}\right) \fallingdotseq 33 \mathrm{~kg}$, 式 (3) から $2 T_{b} \doteqdot 33 \mathrm{~kg}$, 図一10 から $l_{b} \doteqdot 38 \mathrm{~cm}$ が定まる. したがって, $\theta_{t}=0^{\circ}, \theta_{b}=90^{\circ}$ の実験条件に対してボル 卜長さ $l_{b}=38 \mathrm{~cm}$ を用いれば, 落し戸は全ボルト張力 $2 T_{b} \doteqdot 33 \mathrm{~kg}$ ，降下変位 $\delta \doteqdot 1.1 \mathrm{~mm}$ で自立する．これに 対応する実験結果として $l_{b}=40 \mathrm{~cm}$ の場合を挙げれば, 自立時において $2 T_{b}=31 \sim 32 \mathrm{~kg}, \delta=1.3 \sim 1.5 \mathrm{~mm}$ であ る.なお，ここにボルトと地山の相対変位はボルトの引 抜き変位相当する。

実トンネルにおけるロックボルトの設計も上述の考え 方に準じて行うことができる. 素掘りトンネルの解析に よる掘削面の作用力からロックボルトのピッチと設計強 度が求まれば, 所要のロックボルトは引抜き試験結果な ゼを参考にして定めることができる．このとき，素掘り トンネルの内空変位に対してロックボルトの引抜き変位 が小さければ, 変位の推定に後者の影響を無視すること ができる.

弾性的に挙動する地山のトンネルでは, ロックボルト は地山の一体化をねらって用いられる.この場合, ロッ クボルトは少なくともゆるみ部分が崩落しないように設 計する必要がある。なお，トンネルの内空変位を制御す る場合には塑性地山におけると同様に掘削面に作用力を 与えなければならない.

\section{（3）ロックボルトの打設方向その他}

ロックボルトの作用効果として地山の一体化に着目す れば，地山間の相対変位を有効に拘束する意から，ロッ クボルトは引張り材として用いる方が有利である。この 考え方によれば，ロックボルトは地山の主ひずみの方向 に合わせて設置すればよく, 掘削面にほぼ直交して打設

注 4）脚注 2）参照
するのが一般的である。しかし，模型実験結果が示すよ うに，打設方向にはある程度の幅が許容されると考えら れる。なお，ブロッキーな地山ではロックボルトの張力 よりむしろせん断力によって地山の一体化を図らなけれ ばならない場合もある。

地山の安定化に必要な掘削面の作用力をロックボルト に導入するため，塑性地山のトンネルにおいては模型実 験の落し戸板に相当する被覆材が必要である．吹付けコ ンクリートやベアリングプレートなどがこの目的に用い られるが，ロックボルトを有効に利用するには両者を結 合する方がよい．一方，弾性地山のトンネルで掘削面に 作用力を導入する必要がない場合には，原則としてべア リングプレート類が不要になることは明らかである.し かし，ロックボルトの作用効果を確実にするほかブロッ キーな地山の保護などのためにベアリングプレートは有 用である。

\section{7. おわりに}

ロックボルトは NATM の主要部材として多用されて いるにもかかわらず，その作用効果に対する認識がまち まちで，設計の考え方にもいまだ見解が定まらない実情 にある．これは，ロックボルト工が経験に根ざす技術と して発展してきたことによるが，その挙動を解明する実 証的研究手段が欠けていることにも原因があると思われ る. 2 枚落し戸の実験は，このような観点からロックボ ルトが群として挙動する場合のメカニズムを実証的に探 究するため害施したものであるが，1枚落し戸による既 報の研究と同様, この実験がロックボルトの有力な研究 手段として利用できることを示すことができた.

先に行った 1 枚落し戸の実験は, 個々のロックボルト がもつ作用効果を実証的に調べる手段であった。この実 験を通じて，ロックボルトの本質的な作用効果は自己つ り合い作用による地山の一体化にあることを指摘したの は既報のとおりである. 2 枚落し戸の実験においては, ロックボルトが個々の挙動から群として挙動する場合を 対象にしたが，ここにおいても同じ作用効果に支配され る挙動として説明できることが明らかになり，作用効果 に対する再認識を含め, 群としてのロックボルトの挙動 を実証的に究明し，所期の成果をあげることができた。 特にこの実験を通じて, 地山の挙動がロックボルトの存 在に関係なく取り扱い得ることを明らかにできたことに は着目すべきであると思う。また実験結果に基づいて実 トンネルにおけるロックボルトの設計に対しても見解を 述べ，実務への応用を試みることもできた.

わが国における NATM の普及はめざましく，すでに 主たるトンネル工法として認められるまでになってい る. 本研究が NATMにおけるロックボルトの挙動を追 
究し，さまざまな見解を整理する手掛りとして，また設 計手法のモデル化に対する資料として役立つよう願うも のである.

終りにこの研究にあたり，実験は佐藤工業（株）研究 所において大野一昭が担当し，実験結果のとりまとめと 考察は山本 稔が行った。なお，実験にあたっては元佐 藤工業（株）社員 山田 稔氏をはじめ，研究所の関係 者に負うところが多い，記して感謝の意を表わす次第で ある。

\section{参 考 文 献}

1）ロックボルト工設計指針（日本道路公団委託)，昭和 48 年 8 月, 高速道路調查会, トンネル施工分科会ロックボ ルト研究班，なお，文献目録参照。

2）海峡連絡鉄道の技術に関する文献資料調查報告書（日本 鉄道建設公団青函建設局委託)，昭和 55 年 3 月，日本卜
ンネル技術協会.

3）連載講座 NATM（1) (21)，トンネルと地下, 第 12 巻 1 号 第 13 巻 9 号, 昭和 56 年 1 月 昭和 57 年 9 月.

4）第 1 回トンネル技術シンポジウムーNATM におけるロッ クボルト工一昭和 55 年 11 月, 日本トンネル技術協会.

5) 山本 稔: ロックボルトの作用効果について, 土木学会 論文報告集, 第 277 号, 昭和 53 年 9 月.

6) 山本 稔：ロックボルトの作用効果と模型実験, トンネ 儿と地下, 第 9 巻 11 号, 昭和 53 年 11 月.

7）山本 稔・大野一昭：ロックボルトの基礎実験, 佐藤工 業（株）技術研究所報, No. 5, 昭和 53 年; 山本 稔：ロッ クボルトに関する一考察, トンネルと地下, 第 10 巻 8 号, 昭和 54 年 8 月.

8）村山朔郎：砂層内局部沈下部にかかる垂直土圧, 京大防 災研究所年報第 11 号 B, 昭和 43 年 3 月.

9) Terzaghi, K. : Theoretical Soil Mechanics, John Wiley \& Sons, 1943.

(1985.1.17 • 受付) 